\title{
¿Súplica inaudible? Poesía y violencia en poetas colombianas
}

\section{Inaudible Plea? Poetry and Violence in Colombian Poets}

\section{Resumen}

El impacto de la violencia en Colombia, durante todo el siglo XX, exaltado en la intensidad del conflicto armado impuesto sobre la sociedad y la intimidad desde las décadas de los sesenta y mediados de la segunda del XXI, han sido expresados de diferentes maneras por algunos creadores colombianos. Este documento busca llamar la atención sobre algunas representaciones literarias del tema y los efectos poéticos que ofrecen sus autores, al manifestar conciencia frente al dolor que ha causado la guerra. Conscientes de las repercusiones devastadoras de los homicidios, secuestros y desplazados que la violencia ha generado, los autores asumen su rol creativo señalando el horror y, en el caso de las autoras, el énfasis en algunas de una actitud beligerante, profunda desolación y escepticismo. Los estilos son variados y particulares, pues unas reflejan el temblor suscitado por la angustia y el desasosiego, otras expresan rabia o temor, y otras un sentimiento desesperanzado frente a un universo hecho trizas. Son en general voces que expresar dolor individual y colectivo.

Palabras claves Poesía colombiana contemporánea, Poesía de mujeres, Literatura y violencia, Poesía y violencia, Violencia y guerra en Colombia.

\begin{abstract}
The impact of violence in Colombia, experienced throughout the twentieth century, and exalted in the intensity of the armed conflict imposed on society and privacy since the sixties and mid-second decades of the twenty-first, have been expressed in different ways by some Colombian creators. This document seeks to draw attention to some literary representations of the subject and the poetic effects offered by its authors, by expressing awareness of the pain that the war has caused. Aware of the devastating repercussions of the homicides, kidnappings
\end{abstract}


and displaced persons that the violence has generated, the authors assume their creative role pointing out the horror and, in the case of the authors, the emphasis on some of a belligerent attitude, deep desolation and skepticism. The styles are varied and particular, as some reflect the trembling caused by anguish and restlessness, others express anguish with a furious or fearful tone, and others a hopeless feeling in the face of a shattered universe. They are generally voices that express individual and collective pain.

Keywords Contemporary colombian poetry, Women's poetry, Literature and violence, Poetry and violence, Violence and war in Colombia.

Jamás tantos muertos rondaron la casa de los vivos,

jamás tantos vivos habitaron la casa de los muertos.

Nicolás Suescún

Miradme; en mi habita el miedo.

María Mercedes

Carranza

Necesito escribir con vuestra ayuda un libro sobre la guerra. Sobre la manera como la guerra transforma la vida, degrada nuestra vida, nos transforma en seres que se esconden detrás de fantasías inocuas como toreros que se protegen en los burladeros.

Rodrigo Parra Sandoval

\section{La violencia: materia prima para la creación}

Cuando la realidad desgarra, el yo poético se sacude. ¿Cómo no vivir en estado de alarma, si desde hace más de una centuria Colombia ha estado marcada por muchas formas de violencia? Los epígrafes que acompañan este texto revelan temor, pesadumbre, desolación y necesidad de expresar lo que ha significado vivir bajo la zozobra de la guerra. Sus autores, como muchos otros poetas, narradores y creadores colombianos, han manifestado dolor e inconformidad por este flagelo que se ha diversificado en los últimos cincuenta años: Gabriel García Márquez lo hizo en la mayoría de sus obras, por ejemplo en Cien años de soledad (1967) refleja la 
Guerra de los Mil Días, la matanza de las bananeras y la violencia partidista; en Cenizas contra el viento (1950), Hernando Téllez hace ver la tensión dramática del momento; Jorge Gaitán Durán, Emilia Ayarza y Álvaro Mutis plasmaron la violencia y algunos de sus episodios en su poesía; más recientemente Rodrigo Parra Sandoval, Darío Jaramillo Agudelo, Jorge Eliécer Pardo, Laura Restrepo, Evelio José Rosero, Juan Gabriel Vásquez y Héctor Abad Faciolince, entre muchos otros, no desconocen su incidencia en las letras y la han abordado de manera polivalente.

"Jugué mi corazón al azar y me lo ganó la violencia", es el inicio de $L a$ Vorágine (1928), de José Eustasio Rivera, frase convertida en una de las maneras de registrar la persistencia y turbación que este hecho genera, de la misma manera el lienzo de Alejandro Obregón, La Violencia (1962), en el que el cadáver de una mujer representa la geografía nacional. Al hacer una lectura general de la historia del país, desde finales del siglo XIX hasta las dos primeras décadas del siglo XXI, se percibe permanente situación de angustia, al percibir que entramos al siglo XX y salimos de él en estado de alarma.

Es conveniente recordar las repercusiones de algunos acontecimientos importantes sucedidos durante ese período de tiempo: por una parte, el tránsito del siglo XIX al XX en plena Guerra de los Mil Días (1899-1902), protagonizada por los reconocidos partidos tradicionales, el conservador y el liberal, cuyos efectos no solo se dieron en muertes sino en devastación social, política y económica, incluida la pérdida de Panamá en 1903 con la colaboración de los Estados Unidos. Por otra, el impacto generado con el magnicidio de Jorge Eliécer Gaitán en 1948, que dejó por muchos años al país bajo el yugo de la violencia partidista o de medio siglo (1948-1964). Y, posteriormente hasta épocas recientes, diferentes fuerzas problemáticas reconocidas como conflicto armado interno (1964-2015), que ha contribuido a mayor desestabilización y alteración de la sociedad. Conformadas por guerrillas (FARC-EP y ELN), paramilitares, integrantes del estado, narcotráfico, sicariato, delincuencia común, estas fuerzas incluyen secuestro, reclutación forzada, ataques a poblaciones y han conducido a desplazamiento o a exilio. 
A lo anterior se agrega que aunque en el 2016 se firmó el Acuerdo de Paz con uno de los grupos insurgentes (FARC), el país no se estabiliza, debido a situaciones irresueltas entre sus opositores y los desertores del mismo, a lo que se suma la presencia de otro de los grupos insurgentes (ELN) que no ha logrado acuerdos con el Estado, así como la persistencia de parapolíticos, asesinato sistemático de líderes, explotación ilegal de minas, afectación al ecosistema con tala inescrupulosa de árboles en distintas regiones, narcotráfico y otras manifestaciones que generan desconfianza e inseguridad. Ante este último panorama, todo indica que no existe relación con ideologías sino con intereses particulares y diversas maneras de uso del poder.

Muchos han afirmado que la violencia ha sido materia prima para la literatura colombiana, lo que puede verse en algunas obras de Laura Restrepo (1950), Jorge Eliécer Pardo (1950) y Rodrigo Parra Sandoval (1938), quienes desde focos o personajes femeninos narran con horror los tránsitos de la guerra durante el siglo XX y lo que va del XXI, como una forma de salvar del olvido. En La multitud errante (2001), por ejemplo, Laura Restrepo enfoca el desplazamiento forzado como una condena permanente, no sólo propio de la historia de Colombia sino de la humanidad, de ahí que lo asocie con textos bíblicos, entre ellos el Éxodo y el exilio de Caín. Es la experiencia de quienes "huyen de la guerra pero la llevan dentro, porque no han podido perdonar" (Restrepo 101). La narrativa de Pardo concentra la violencia como la continuidad de un río desbordado que viene desde inicios del siglo XX. Parra Sandoval la enfoca de lo particular a lo general, al relacionarla con los momentos fundacionales, es decir, desde el descubrimiento de América y la relaciona con el engranaje de los conflictos irresueltos de nuestra historia, y al mismo tiempo la relaciona con otras historias y catástrofes mundiales.

Interesa aquí destacar la perspectiva femenina de estos autores. Varios son los focos narrativos de La multitud errante: Ojo de Agua, Matilde Lina y Perpetua. El personaje central, Siete por Tres, o Veintiuno, es narrado por cada una de ellas. Desde el comienzo, este personaje busca infructuosamente a Matilde Lina, a quien dolorosamente ha perdido durante su peregrinaje de lugar en lugar. Asumida como 
madre protectora y ángel guardián, Matilde es el arraigo, la raíz, la tierra, la mujer amada y deseada. Perder a Matilde es perder la madre, la patria y la memoria. La historia de Siete por tres comienza, como dice la voz narradora, Ojo de Agua, "el día de su nacimiento, primero de enero de 1950" (Restrepo 25), cuando apareció abandonado "en los escalones del atrio de una iglesia todavía en obra que inauguraban prematuramente para celebrar la llegada del cincuenta" (25), época en que se vivían "los ecos de la Guerra Chica, que cundía desde el asesinato de Jorge Eliécer Gaitán" (Restrepo 26).

Ojo de Agua ve en él su mirar hacia adentro, su destino y la dificultad para establecer vínculos:

Saber cómo se llamaba este desconocido que tenía al frente era la única manera - al menos así lo sentí entonces - de contrarrestrar el influjo que empezó a ejercer sobre mí desde ese instante. ¿Debido a qué? No podía precisarlo, porque no se diferenciaba gran cosa de tantos otros que viene a parar a estos confines del exilio, envueltos en un aura enferma, arrastrando un cansancio de siglos y tratando de mirar hacia delante con ojos atados a lo que han dejado atrás. (17)

Al focalizar a Siete por Tres, Ojo de Agua se presenta como la mujer que puede rescatarlo del desamparo. Alter ego de la autora, rige el discurso y se compromete tanto con la historia y el relato como con el desgarramiento por las circunstancias vividas y la intensidad de las sensaciones. Sus reflexiones corresponden a las que en sus épocas de estudiante universitaria aprendió con René Girard que "la violencia nunca es irracional, que nadie como ella para llenarse de razones cuando quiere desencadenarse" (37). Usual en la escritura de Restrepo, esa narradora autorreferencial es una intelectual que en su escritura asume el control ante los marginales y la desazón frente el mundo perdido o hecho trizas, en este caso asumido con el personaje peregrino desde sus orígenes, cuando fue abandonado por unos padres que no eran malos sino tristes, como le dice Matilde 
(30). Siete por Tres la llama Ojo de Agua, y sabe que ella reconoce su condición enajenada y el dolor de ser protagonista de la violencia y el desplazamiento, de carecer de nombre y responder a un número, analogía de otros de su misma condición "en medio de un país que se niega a dar cuenta de nada ni de nadie" (53).

Perpetua conoce otras aristas de la historia del personaje y de la violencia en la que los niños crecen a tenor del peregrinaje, del hambre, del miedo, del frio y sin pertenencias, pues ella "se hallaba presente en el atrio de aquella iglesia [...] la noche en que encontraron al niño de pie quimérico" (43). Ella conoce su culpa, "la de no haber impedido que se la llevaran. De no buscarla con suficiente empeño" (56).

La novela redunda en el sentimiento de pérdida. Si Veintiuno es desde sus orígenes un ser que ha perdido sus referencias, como consecuencia pierde a Matilde Lina, único punto de apoyo, de la misma manera que Ojo de Agua lo pierde a él, y no podrá encontrarlo o rescatarlo, no solo porque él es escurridizo y desconfiado sino porque desde siempre hay distancia entre los dos:

comprendo que esa forma de llamarme es constatación de distancia: ojos claros son de otra raza, de otra clase social y otro color de piel; de otra educación, otra manera de agarrar los cubiertos en la mesa, distinta forma de dar la mano al saludar, de reírse de otras cosas; otra manera, dificultosa y fascinante: definitivamente otra. (79)

Él no regresará jamás, pues está condenado a vagar en el limbo, como una suerte de Caín errabundo y sin destino en medio de ese río de gente que, como la guerra, no se detiene, "no cesa, cambia de cara no más" (32-39) y se repite de peregrinación en peregrinación (62).

En sus diversas novelas y cuentos, con una lírica de tono nostálgico que rescata la memoria, Jorge Eliécer Pardo ofrece generalmente figuras femeninas como centro o foco de los relatos. Precisamente, si miramos ese conjunto de treinta y dos relatos acompañados de cuarenta y cinco fotografías de mujeres cubiertas 
por un velo, Los velos de la memoria (2014), como indica su título, sugiere un viaje por la historia de Colombia. La metáfora del velo muestra la necesidad de cubrir el miedo y el dolor por las pérdidas. Pero velar es también develar y revelar la orfandad, el vacío, la desolación. Cada relato abre una ventana y muestra un efecto, una o más circunstancias que nadie quisiera vivir o repetir.

Violencia y miedo se entrelazan desde el primer texto hasta el último, como en un desdoblamiento continuo de épocas, lugares y masacres, así como modos y circunstancias, agentes y hechos que reflejan el estado de alarma. Es reconocido el relato "Sin nombres, sin rostros ni rastros", premiado en el 2018 en el concurso nacional de cuento sobre desaparición forzada. Dedicado "a las amorosas mujeres de Colombia", una sucesión de elementos sintetiza motivos reveladores de la violencia. Desde el primer párrafo impacta la voz femenina que busca exorcizar el dolor y dar entierro a los muertos ajenos, como si fueran propios:

Como a mis hermanos los han desaparecido, esta noche espero a las orillas del río a que baje el cadáver para hacerlo mi difunto. A todas en el pueblo nos han quitado a alguien, nos han desaparecido a alguien, nos han asesinado a alguien, somos huérfanas, viudas. Por eso, a diario esperamos los muertos que vienen en las aguas turbias, entre las empalizadas, para hacerlos nuestros hermanos, padres, esposos, hijos. (Pardo 85)

"Los rostros del río", ofrece una metáfora reveladora de la tensión de quienes esperan noticias de los sobrevivientes y necesitan construir la memoria:

Solo los niños pueden ver rostros reflejados en el agua. Identifican padres, hermanos, tíos, primos, amigos y vecinos. Al salir de la escuela y, sin que los mayores se enteren, van al río. Recorren un kilómetro saltando peñascos hasta donde el agua se tranquiliza, sosegada, paciente, en pequeñas ondulaciones. Hombres, mujeres y algunos niños sonríen en la transparencia. Distinguen caras a pesar de que los cuerpos fueron 
enterrados, desenterrados y vueltos a enterrar en diligencias de legistas y sepultureros. (Pardo 101)

Si la memoria es contaminada por extraños la relación tiempo-río pierde su misterio: "Los nuevos niños de la ciudad no aprenden a leer las aguas putrefactas y espumosas del río que atraviesa suburbios con olor nauseabundo y aves de rapiña devorando la carroña" (102).

Por otro lado, entre autores determinantes debe reconocerse al sociólogo y narrador Rodrigo Parra Sandoval, quien en diferentes novelas ha hecho su propia cartografía, al recorrer en ellas determinadas épocas y regiones, y reconocer formas de violencia que determinan relaciones y conflictos sociales, culturales y de conocimiento ligados a diferentes maneras de autoritarismo y sumisión presentadas como partícipes de la educación.

Ya en su primera novela, que en su momento fue claramente transgresora, El álbum secreto del Sagrado Corazón (1978), entre la diversidad temática y formal de los ocho álbumes que la estructura, de manera paródica se revisan nuestra historia y aprendizajes, deteniéndose en los rasgos identitarios de nuestra y en las marcas dejadas por la educación religiosa y los principios orientados por las diversas clases sociales. Esta temática se redimensiona en Tarzán y el filósofo desnudo (1996), que con gran sentido del humor muestra el despotismo ilustrado en el mundo universitario, al que pone en crisis mediante la crítica juguetona a profesores y su asimilación de teorías extranjeras que aplican al conocimiento de la realidad nacional, y así mismo destaca los abusos definidos en el autoritarismo del sistema educativo. De otra manera, Museo de lo inútil (2007) presenta la violencia en una representación que va de lo general a lo particular: si por una parte, en un contrapunto narrativo entre padre e hija se sopesan tradición y renovación, por otra fluyen multitud de relatos y asuntos, entre ellos el de la espera de una intervención quirúrgica que devuelva movilidad a las piernas de esa hija que ha sido víctima de las minas "quiebrapatas" usadas como recurso bélico por las guerrillas a fines del siglo XX. De forma alterna los dos personajes relatan historias y conjeturas, 
debaten sobre la estructuración de una novela actual, y con distintas analogías se refieren al mundo que se desintegra al pulverizarse, como cuando explotó el Big Bang y se creó lo que conocemos como universo, o como cuando se observa la célebre pintura de Max Ernest, "Explosión de una Catedral", y se alcanza a visualizar la figura fantasmagórica de lo que aquello era. La carga del impacto destructivo que proyectan las imágenes corresponde a la refracción de un hecho sucedido en la década de los cincuenta y que fue signo de la época, durante la presidencia de Gustavo Rojas Pinilla. Se trata de la explosión de unos camiones en un sitio emblemático de Cali, ciudad colombiana, circunstancia que sumió a la sociedad en estado de conmoción.

Desde otra perspectiva, uno de los personajes femeninos que atraviesa la obra de Rodrigo Parra Sandoval es Micaela, quien asume el rol de voz narrativa en Faraón Angola (2011). En esta novela ella afirma que la historia de la violencia en Colombia es de nunca acabar. Se trata de "historias de lo que le pasa a la gente en medio de la guerra" (53), de los asaltos y las llamadas "pescas milagrosas" en las carreteras, de los secuestros, de las violaciones, las muertes, las bombas, los heridos, los hijos y los padres que ha quitado "la guerra que lo transforma a uno" (65).

Estructurada como un viaje por el territorio y al mismo tiempo por la geografía nacional en su zona central, Micaela "da testimonio de la trastada que la guerra hace con la vida" (54). La reiteración de la palabra "guerra" sostenida por la voz narrativa habla de la patria y el paisaje, del amado perdido y el amor, de los sueños rotos y la música, de la escritura como un acto de liberación y resistencia frente a la historia amenazante del país, vivida desde la prehistoria, cuando pasaban "hombres cobrizos desnudos, con la cara pintada o cubierta de máscaras de oro, armadas con flechas y lanzas que perseguían con un lento pasitrote a otros hombres cobrizos [...]" (79). Correlato que se relaciona en otros cambios narrativos que asumen otras temporalidades, como cuando la mirada recae sobre la conquista. La voz narrativa ve pasar: "hombres desteñidos, blancos, como untados de harina de maíz, de barbas largas, forrados en armaduras de lata que el sol del trópico convertía 
en saunas ambulantes, montados en caballos al trote, que perseguían con sus espadas y sus armas de trueno a hombres cobrizos desnudos con la cara pintada [...]" (79).

De la misma manera, la historia avanza tres siglos más con los ejércitos de la reconquista, hasta llegar a las modalidades guerreras del siglo $\mathrm{XX}$, aludiendo a los conflictos bipartidistas y sus peleas entre liberales y conservadores, para de manera burlesca decir que unos y otros son iguales: "valientes bandoleros con banderas azules que persiguen heroicamente a valientes bandoleros con banderas rojas que corren en desbandada. Quieren sacarles las tripas, siempre quieren sacarles las tripas a los otros, y colgarlas de las ramas bajas de los árboles [...]" (80).

El correlato histórico llega a los matices del conflicto armado y su cargamento de horror y muerte. Se trata de mostrar ese trasegar bélico en una permanente espiral que gira sin cesar: "un círculo obstinadamente cerrado sobre sí mismo que nadie ha logrado romper" (124).

Por otro lado, Voto de tinieblas (2012), narrada también por sendos personajes femeninos, una monja de clausura y una antropóloga forense, constituyen una forma de desdoblamiento de la voz que revisa alternadamente la mentalidad medieval y la contemporánea, al contraponer el pasado colonial con el tránsito de los siglos siguientes hasta llegar al siglo XXI. Desde la invención de la historia y de la arqueología, las dos voces femeninas asumen la tarea de contar. Se trata de una escritura creativa, analítica y reflexiva que como una forma de exhumación busca tomar conciencia de la historia, contarla o escribirla para conocerla, entenderla, explicarla y evitar olvidarla.

Desde los muros de la celda de la monja se perfilan esqueletos de seres anónimos perfectamente envueltos. Son "textos históricos" que hablan del pasado. Al mismo tiempo, la vida de afuera sucede en la escritura de la monja que utiliza su cuerpo como página para narrar lo que imagina ha sucedido o va sucediendo. Paralelamente, en el presente resuena la voz de la antropóloga forense, que intenta descifrar unos huesos insepultos o escondidos como NN, para darles nombre e 
historia, ya que sabe que "los huesos son textos" (Parra Sandoval, Voto de tinieblas 257). Tanto en las ruinosas y oscuras paredes del claustro, como en la polvorienta tierra del presente se está frente a vestigios de individuos innominados que la historia oculta. Gracias al desdoblamiento de los personajes, la voz de una va a la voz de la otra: la monja escribe su autobiografía apócrifa y la antropóloga interpreta la historia con el "arte de los huesos". Las dos hacen la cartografía y siguen la geografía de la muerte; saben, como escribe la monja, que "no es fácil vivir en la oscuridad rodeada de tantos huesos" (266), a lo que replica la antropóloga refiriéndose a otros pasados: "Dieron también con la práctica de cubrir zócalos de sus casas con huesos organizados en formas geométricas" (Voto de tinieblas 135). La historia de esos huesos refleja el paso por la vida y por la muerte, analogías que buscan ser desentrañadas para entender la historia e intentar que no se repita más. Se trata, definitivamente, de sacar a la luz la historia oculta, de hacer memoria, de quitarle a la historia los velos mediante la escritura, la lectura, el análisis y la interpretación, y asumir de manera consciente nuestros dolores y vergüenzas.

\section{Un pájaro negro husmea en las páginas de la poesía}

No sobra recordar la contundente frase: "las palabras están en situación", de la página editorial del primer número de la revista Mito (1955-1962), en la que se manifiesta la necesidad de estar a tono con el momento histórico. Muchos de los autores de esa generación expresaron su posición ante la violencia de medio siglo, entre ellos Gabriel García Márquez en La hojarasca (1955), El coronel no tiene quien le escriba (1961) y gran parte de su obra; Álvaro Mutis y Fernando Charry Lara en su poesía, Héctor Rojas Herazo en sus novelas y obra poética y pictórica, como por su parte lo hicieran los artistas plásticos Alejandro Obregón y Fernando Botero. Más recientemente, obras como la de Doris Salcedo ha sido contundente al respecto.

Esta conciencia que surge a mediados del siglo XX resuena unas décadas después, cuando en mayo del 2003 la Casa de Poesía Silva convocó a un concurso nacional bajo el lema "Descanse en paz la guerra", como una forma de manifestarse 
contra la truculencia que azotaba al país. En breve texto publicado en el periódico El Tiempo, el poeta Juan Manuel Roca invitó “a oponerse al recrudecimiento de la guerra, desde la amplitud de matices y creencias que permite la poesía. Más aún, cuando al largo conflicto se le suma un estado de emergencia cultural"1. Casi siete mil poetas se presentaron a la convocatoria que otorgó veinte premios.

Pasados unos años, el mismo Roca publica la antología titulada La casa sin sosiego. La violencia y los poetas colombianos del siglo XX (2007), con prólogo de León Valencia, en la que incluye poemas de siete mujeres y cuarenta y cuatro hombres nacidos entre las décadas del veinte a los setenta, en cuya introducción Roca refiere los antecedentes en la colonia y su prolongación a nuestros días. En el 2017 se publica la segunda edición, prologada por el poeta mexicano José Ángel Leyva, a la que agrega poetas nacidos en los ochenta. En las dos ediciones la muerte está presente y habita "la patria violenta", camina por cementerios y calles sucias, pasa por "vuelos mórbidos", por la sangre como "lluvia roja", o por el rojo como "lluvia sostenida en el aire", por cuerpos desmembrados, por guerreros y ataúdes, por fusiles y asesinos, por desplazados forzosos, por tenebrosos sicarios; en fin, por esa constante pesadilla en "muchos se arman para la guerra". Precisamente, en mayo del 2018, en la presentación de esta segunda edición en la Feria Internacional del Libro de Bogotá, la poeta colombiana Piedad Bonnett afirmó: "Estos poemas están cargados de cadáveres, de sobrevivientes, de rastros de sangre, de noticias de periódico, de hombres que van a morir en unas horas o que van a matar en unas horas, de madres y padres y sueños rotos, y de miedo, de mucho miedo (Recuperado de http://www.laraizinvertida.com/detalle-2365-la-casa-sin-sosiego-la-violenciay-los-poetas-colombianos-del-siglo-xx)

Si hacemos una lectura transversal de la poesía colombiana escrita por mujeres, son varias las poetas contemporáneas que se expresan de manera personal ante el desastre. Las que crecieron durante la época de la violencia del medio siglo, coinciden en muchos aspectos con las nacidas entre las décadas de los 70 a los 90 .

${ }^{1}$ Descanse en paz la guerra, documento MAM-983755. Archivo digital. Noticias Colombia www.eltiempo.com consultado en septiembre 4, 2020. 
En cada una de ellas se perciben diversas maneras de asumir la zozobra y despedir el idilio. Tal es el caso de poetas como María Mercedes Carranza (1946-2003), Piedad Bonnett (1951), Miryam Alicia Sendoya (1950), Mery Yolanda Sánchez (1956), Luisa Fernanda Trujillo (1960-2020), Beatriz Vanegas Athías (1970), Camila Charry (1979), Andrea Cote (1981), Diana Carolina Sánchez (1982). Se trata de una poética de la guerra, de la muerte y de la fragmentación; unas con lenguaje directo y otras de manera alusiva se refieren a los hechos transmitiendo angustia, vacío, miedo, rabia, ante el luto multiplicado, la sangre imposible de lavar, la queja por los muertos, el anonimato. Pájaros negros o sin alas, revolotean en muchos de esos poemas.

Ante la expansión de la violencia, lo idílico no tiene cabida o no alcanza a consolar. En términos generales, la poesía cultivada por algunas poetas ha tendido al intimismo, a la expresión de temas universales orientados hacia la reflexión sobre la existencia, a la vida doméstica y la conciencia del tiempo que pasa, aunque paulatinamente algunas se desplazan hacia lo social y lo erótico. A tono y en consecuencia con la crisis e inestabilidad de los valores tradicionales y la presión ejercida en todos los lugares donde amenaza la guerra, muchas autoras cambian su registro y se detienen en la truculencia, señalan la inestabilidad de las instituciones, la pérdida de certeza y la relativización de las convenciones. Roto el idilio, resulta necesario manifestarse ante un mundo quebrantado, herido, hecho trizas. La lectura de algunos poemas obliga a un seguimiento zigzagueante entre autoras, y a aprovechar las reflexiones realizadas en el amplio prólogo de la antología Ellas cantan. Antología de poetas iberoamericanas (2019).

María Mercedes Carranza es considerada de ruptura, especialmente frente a la poesía escrita por mujeres; pertenece a la llamada Generación sin nombre que surge a fines de la década de los 60 , cuando se llamó la atención sobre algunos poetas que empezaban a dar a conocer sus primeros libros o poemas². Precisamente,

${ }^{2}$ A mediados de la década de los 80, con prólogo de Antonio Caballero, Harold Alvarado Tenorio preparó una la antología que tituló Una generación desencantada, en la que incluyó a algunos poetas que dieron origen a la llamada Generación sin nombre y a otros contemporáneos, como él mismo, al lado de José Manuel Arango, Giovanni Quessep, María Mercedes Carranza, Juan 
registraron el surgimiento de una nueva generación de poetas colombianos la publicación en Lecturas Dominicales de El Tiempo (1967), del artículo "Una generación busca su nombre”, de Álvaro Burgos Palacios; de una selección poética en el n ${ }^{\circ} 19$ de la revista argentina Cormorán y Delfín (1969); y la Antología de una Generación sin nombre (1970), elaborada por Jaime Ferrán para editorial Adonais en Madrid. Si bien ninguna de estas publicaciones incluyó mujeres, con el paso del tiempo se amplió la nómina de coetáneos y fueron agregadas María Mercedes Carranza y la uruguaya Martha Canfield radicada entonces en Colombia. No sobra decir que siguieron muchos otros artículos y selecciones, y que al celebrar cincuenta años de su existencia en 2019 no solo se publicaron antologías actualizadas, sino se ratificó su importancia en el canon de la poesía colombiana.

Algunas autoras anteriores a Carranza, como Matilde Espinosa (1910-2008) y Emilia Ayarza (1919-1966), resultan contestatarias y menos "políticamente correctas" frente a aquellas en quienes prevalece la evocación y la ensoñación lírica. Espinosa acude a la cotidianidad y la tragedia del pueblo, Ayarza a lo social. Ante la violencia resultan emblemáticos y conmovedores los poemas "A Cali ha llegado la muerte”, de Ayarza y "¡Los ríos han crecido!”, de Espinosa. En el de Ayarza, escrito a raíz de la misma explosión de camiones de dinamita referida en la novela de Parra Sandoval, se afirma: "El rojo fue una lluvia sostenida en el aire/ y entre los montes de cristal la sangre/ dibujará para siempre vitrales en la sombra" (Roca 42). Y en el de Espinosa el poema que da título al libro publicado en 1955 dice: "En su vientre, los ríos/ levantan cementerios/ y la muerte se cierra/ en círculos morados [...]. / En las gradas del alba/ subiendo esqueletos/ con su carga madura/ de grávidos espinos, / y una afrenta de espigas/ que hace temblar la hierba"

Manuel Roca, Darío Jaramillo Agudelo y Juan Gustavo Cobo Borda. Por fuera del grupo fundacional quedaron: Álvaro Miranda, Jaime García Maffla, David Bonnells, Henry Luque Muñoz, Augusto Pinilla y José Luis Díaz Granados. En el prólogo, Caballero toma como punto de unión de los poetas el desengaño y el temor a la retórica tradicional, destaca el prosaísmo, el humor, la cultura, la inteligencia, la lucidez y, especialmente, la desconfianza en sí mismos y en la propia poesía. 
(Recuperado de https://diariodepaz.com/2019/05/17/los-rios-han-crecido-matildeespinosa/)

Desde 1968 hasta su muerte en el 2003, con lenguaje prosaico y profunda ironía, la poesía de Carranza habla de desilusión y muerte, y agudiza la expresión de dolor, declarándose "infeliz sobreviviente de una muerte/ que forma parte del paisaje" como dice en "Huele podrido", de uno de sus últimos poemarios, Maneras del desamor (1990-1992) (Carranza 121). En "Aquí entre nos", Vainas y otros poemas (1968-1972), de su primer libro, el yo poético afirma: "llenaré las páginas que me falten/ con esa memoria que me espera entre cirios,/ muchas flores y descanse en paz" (19); en su segundo poemario, Tengo miedo (1976-1972), en "Ledesma, 1951" sostiene: "La vida era aún los desastres de la guerra" (59), y al referirse al amor, en "Balance final" reconoce la degradación y la contaminación de la muerte: "Luego y antes y ahora y para siempre/ todo fue un juego de espejos enemigos:/ solo hubo rechazos, cuerpos solitarios,/ mal aliento, ilusiones no compartidas,/ cartas banales, gestos rutinarios/ y un paciente velar el cadáver del instante" (46).

Los poemas entrecruzan escepticismo y desencanto en la palabra que, como un ejercicio de Sísifo, recae en el acto constante de ordenar sin sentido, lo que se asimila al amor y a la vida misma en su hacer y deshacer las tareas domésticas. Así se percibe en "Oda al amor", uno de los poemas de Hola soledad (1985-1987): "hacer de nuevo la casa,/ reacomodar los muebles, limpiar las paredes,/ cambiar las cerraduras, romper retratos,/ barrerlo todo y seguir viviendo" (92).

Nada se salva de la desacralización, ni el amor, ni la idea del poeta como dios, ni la poesía como iluminación, ni el enaltecimiento de la patria, mucho menos la poesía que considera inútil. El nombre de un bolero da el tono a partir del título de ese tercer libro, en el que se expande el desencanto en el fin de la juventud, en la nostalgia por lo que ya no existe, en lo olvidado y ruinoso, y en la patria agonizante que aproxima a un cementerio. Así se percibe en "La Patria": "Todo es ruina en esta casa. Las ventanas muestran pasajes destruidos, / carne y ceniza se confunden en las caras, / en las bocas las palabras se revuelven con el miedo. / En 
esta casa todos estamos enterrados vivos" (Carranza 81).

Enfatizan en la violencia un poema de 1990 y un poemario de 1998, titulados respectivamente: "18 de agosto de 1989" y El canto de las moscas (Versión de los acontecimientos) (1997-1998). El primero se refiere al día del asesinato en una plaza pública de su amigo el candidato presidencial Luis Carlos Galán, cuya bandera política perseguía el sueño de un país su libro en paz. Alegoría y elegía, con la reiteración del verso "este hombre va a morir", el poema anuncia la muerte del héroe, y al iniciar cada una de las cuatro primeras estrofas y cerrar la quinta con la caída de cuerpo, revela la sangre y la muerte de los sueños. Una suerte de corifeo escrito en cursivas al final de cada estrofa focaliza y reitera cuatro veces la imagen de degradación del asesino: "En su corazón de piedra/ el asesino afila cuchillos", "El asesino esconde la cara siempre/ para que el sol no le escupa sus gargajos de fuego”, "El asesino: humores de momia, hiel de alacrán, / heces de ahorcado, sangre de Satán”, “Todas las lenguas de la tierra maldicen al asesino” (103-105).

El poemario El canto de las moscas (Versión de los acontecimientos) (19971998), es un canto elegíaco sobre distintos episodios que reiteran el horror de la violencia, escrito en veinticuatro cantos breves. Similar a una mosca que zumba con metafórico vuelo, cada canto es un señalamiento de guerra y un canto fúnebre. Brevísimos versos de pesadumbre frente a esos veinticuatro lugares y crueles sucesos poetizados para que al menos permanezcan en la palabra poética; veinticuatro escenarios de la geografía nacional que fueron territorio paramilitar donde sucedieron espeluznantes masacres. Son significativos algunos ejemplos en los que se despliega la imagen de las moscas y se escucha su zumbido de muerte, el grito por la patria que se desangra y la orfandad que crece, la soledad, el terror, el quebrantamiento. Comienza con "Necoclí" diciendo: "el próximo instante [...] se oirá nada más/ el canto de las moscas" (125) y avanza de poema en poema como un caleidoscopio que recorre escenarios; en "Mapiripán" los lugares se pierden y todo "es ya una fecha" $(2013,126)$; en Dabeiba" se ven ríos con rosas rojas que "no son rosas, / es la sangre/ que toma otros caminos" (128). En "Uribia" la muerte se 
acumula: "Cae un cuerpo/ y otro cuerpo. / Toda la tierra/ sobre ellos pesa" (137); con inquietante ironía "El viento/ ríe en las mandíbulas de los muertos", como dice en "Ituango" (144); en "Tierralta" es conmovedora la manera como destaca lo que fue y lo que es en un delicado recorrido por el rostro del amor: "Esto es la boca que hubo, / esto los besos. / Ahora solo tierra/ entre la boca quieta" (131). El lenguaje alusivo del poema que cierra el libro, "Soacha", es altamente doloroso: "Un pájaro/ negro husmea/ las sobras de/ la vida. / Puede ser Dios / o el asesino:/ da lo mismo ya" (148). Imposible desligarse del sentido: husmea el pájaro de la muerte, está atento al cadáver que lo alimenta. Y el escepticismo: ¿quién es responsable?

Hechos similares llegan a la poesía de otras autoras, en los que se impone el lenguaje fragmentado, como cuando al referirse a los horrores cometidos por los violentos en Chengue, tanto Beatriz Vanegas Athías como Camila Charry Noriega hacen visibles las situaciones. Por un lado, con imágenes visuales y auditivas que se deslizan de una a otra, Vanegas Athías sugiere de manera condensada lo ocurrido, y hace que la crueldad transcurra en el poema "Rastro del horror", como si una cámara cinematográfica pasara por el lugar de los acontecimientos: "Entonces pasaron adelante, / acomodaron el rostro sobre la piedra:/ una mano sostenía, otra asestaba. / Luego fueron los golpes secos de la mona: veintisiete exactos golpes/ sobre la piedra que mató a Chengue" (Vanegas Athías 62-63). Resuena el sonido de los "veintisiete exactos golpes sobre la piedra" y el final de todo un pueblo, cuando precisamente dice: "sobre la piedra que mató a Chengue". La voz asume el cinismo de la guerra, y para no guardar silencio usa frases marcadas, enumera lugares, situaciones, "súplicas inaudibles", "nacimiento de muñones" y "gasa clausurando las palabras", como en "Nada anormal" (66), en el que termina de manera circular y retoma el título del poema e indica que es un hecho repetido.

Con similar contundencia, en un poema también visual y auditivo, "Chengue", Charry enfatiza en el horror frente a la violencia y los fragmentos que deja la muerte, al simular la transmisión de una noticia radial y replicar con tono oral, dando la sensación de ahogo y tartamudeo: Que hubo explosiones, / restos de 
carne que se estrellaron contra otros cuerpos. / Que todo fue muy rápido. Que las gallinas dejaron en el aire/ después de arder bajo el estallido/ sus plumas como un ala de neblina/ que no permitió ver con claridad/cuándos muertos fueron" (Charry 34)

En "Saga de los desterrados", para referirse a la ruina del mundo sin el fuego, Vanegas Athías alude al mito de Prometeo y evoluciona a un verso incisivo que hace referencia a un "país de cuervos ahítos/ y de lágrimas prohibidas" (42), así como en otros de sus poemas Charry acude a la mitología familiar y la condensa en la simbiosis casa-patria. Casa y patria se deshacen conteniéndose y buscan albergue en la palabra poética, como en los respectivos "Éxodo" y "Patria". Con imágenes que se superponen a lo humano, en el primer poema se afirma que los árboles se ahogan, los animales yacen, se van los pájaros, las moscas zumban y es necesario abandonar la casa que "ordena a sus muertos" (Charry 25-26). focalizan a un niño cuando "revienta sobre su cuerpo el fusil del asesino" (63), en el segundo destaca una escena oprobiosa.

En el poemario Cae sobre mí una sombra (2018), Diana Carolina Sánchez Pinzón se refiere a otra masacre y muestra un cuadro de horror, aclarando en pie de página que en el 2002 se dio un combate entre la guerrilla y los paramilitares en el que una pipeta bomba estalló en la iglesia del pueblo causando la muerte de 119 personas. El título del poemario es altamente sugestivo: la caída de una sombra es analogía del peso de la agobiante y cruenta historia. El título del poema es tan explícito como sus imágenes: "Masacre de Bojayá". Son notables las sugerencias dadas a partir de la fragmentación que se sostiene inicialmente en los cuerpos y los ventanales, y el carácter alusivo desde el sentido de la vista que permite ver el despilfarro de la crueldad: "Los vidrios en el suelo/ son manchas de sangre multiplicadas/ [...]/. Existe Cristo/ con los brazos abiertos y sin cabeza. / Y alguien/ dispara" (Sánchez Pinzón 42).

Cada imagen refleja lo que dejó el hecho violento, pero el efecto mayor de ruina, desamparo y tragedia recae en el crucifico descabezado que se impone sobre las víctimas. Todo y todos están hechos trizas y son eco de los flagelos que han 
causado lágrimas y han cercado el "campo/ como alambres de púas" (42). Sin duda alguna esos alambres atraviesan el tiempo y el espacio y aluden tanto al Holocausto como a las víctimas del secuestro, entre ellos los soldados prisioneros de las FARC por mucho tiempo y cuya fotografía circuló en la prensa mundial. Sánchez se expresa con imágenes de mutilación, horror, pesadilla, como en "Metamorfosis", donde una cabeza flota perdida "entre los ojos de Dios" o "en cualquier basurero" y hace ver que la vida no es más que "comida de moscas" (15).

No sobra tener en cuenta el contraste entre la condensación de Diana Carolina en su poesía y el carácter descriptivo de Álvaro Miranda y Jorge Eliécer Pardo, al referirse en sendos textos a la misma masacre. El poeta y narrador Miranda, narra con agudeza crítica la situación y enuncia el sinsentido de la violencia en "Lo que pasó en Bojayá", largo texto poético de su libro La otra épica del Cid (2010), incluido en la antología de su poesía El bostezo de la mosca azul (2020):

E1 2 de mayo del 20 murieron entre 74 y 119 habitantes de Bojayá. Fueron bombardeados. Del cielo, uno de los bandos en guerra, la guerrilla colombiana, les arrojó una pipeta de gas propano, como respuesta al bazucazo que acababan de recibir de las autodefensas paramilitares. El cilindro mortal lleno de gas cayó sobre la capilla de la humilde población y adentro de ella, los refugiados de la vida civil que poco entendían de esa guerra que no era suya.

La muerte, como una flor que esparce sus pétalos había llegado para quedarse ahí como nuestro Guernica, como parte de un combate territorial entre dos grupos en conflicto que volvieron lo verde del paisaje en un lienzo de tonos grises en blanco y negro.

[...] El caos, el olor a sangre, los gritos y el escape para donde fuera comenzó a darse. Corrían hacia la ciénaga detrás de la iglesia y los heridos fueron cargados y llevados a la casa cercana de las monjas. Ellas, activas y solícitas, sirvieron de enfermeras en los primeros auxilios. Hubo otra 
pipeta en explosión. Los paramilitares huyeron y el padre Antún, atento s sus fieles, recuerda como unas guerrilleras que habían entrado a la capilla, decían: 'Jueputa, ¿Qué hicimos? Matamos a mujeres y niños' y se pusieron a llorar maldiciendo la guerra. (Miranda 57-59)

Realidad y poesía muestran sensorialmente la crueldad de los hechos, mediante imágenes reveladoras del horror de "nuestro Guernica", de la muerte "como una flor que esparce sus pétalos", del color gris y la misma angustia por lo causado. Jorge Eliécer Pardo narra el mismo suceso en "Milenia", de Los velos de la memoria, y logra que el ritmo de la prosa poética alterne con el sentido de la crónica y los hechos que se deslizan con cierto detalle:

Minelia se escondió debajo del árbol al escuchar los disparos que traía el río desde la ribera. Los guerrilleros entraron a Vigía del Fuerte y asesinaron a veintiún policías y se llevaron diez sin antes sacar de sus casas a ocho pescadores a los que dieron dictamen de auxiliadores de los paramilitares y fusilaron arrodillados.

[...] A las seis de la mañana desde los puntos donde se atrincheraban los guerrilleros, empezaron a disparar. Minelia corrió a busca al padre Antún. Por las calles la gente despavorida llevaba a sus niños en los brazos para protegerlos en la casa de Dios. Más de trescientas personas se refugiaron en los ciento diecisiete metros cuadrados de templo de San Pedro Apóstol. Las ráfagas seguían y el círculo se achicaba.

[...] Minelia contaba historias a los niños para que las ráfagas no los asustaran. [...] Los paras y la guerrilla afianzaban posiciones y los rezos seguían murmurados dentro de la iglesia. Miraban los ojos suplicantes del Cristo y le pedían piedad para con sus hijos. [...] Minelia cantó una tonada lastimera que nadie había oído, como si quisiera adormilar a los hombres en combate. Pero la madrugada del miércoles, dos de mayo, llegó con más disparos y gritos. [...] De pronto sonó un bombazo que hizo estremecer la 
tierra, una pipeta de gas lanzada por la guerrilla desde la distancia, en busca de sus enemigos. [...] Las madres cubrían a sus hijos y Minelia no dejaba de cantar. Detrás de la iglesia una escuadra de paramilitares respondía el fuego. Minelia dejó de cantar porque escuchó el silbido de la tercera pipeta, el cilindro venía directo al techo de la capilla. Como rayo fulminante estalló contra las tejas y dejó escapar sus desperdicios: explosivos, pedazos de hierro oxidado, cachas de machetes, fragmentos de baterías viejas, piedras y costales, clavos y vidrios. (Pardo 15-24)

\section{Las guerras incontables y el zumbido de las moscas}

La muerte es irónicamente "natural en esta guerra", se multiplica en un hangar, en un vagón, en cualquier lugar, dice Piedad Bonnett en su poema "Mapa", incluido en la antología Ellas Cantan. Poetas iberoamericanas:

un hombre muerto/ con un nombre inservible como un cántaro roto. /Un hombre muerto de cara a la luna, / o de bruces quizá, como un chico, / anonadado y solo, cejijunto, / un hombre muerto-muerto a pesar suyo. / Sin talismán, sin aire, sin esperma/ un hombre sin domingo por la tarde/ muere a las dos y media/, muere tres veces hoy y seis mañana/ de muerte natural en esta guerra. (Giraldo 146)

Algo similar se dice en el poema "Cuestión de estadísticas", en el que de manera enumerativa y sintética habla de una realidad conocida:

Fueron veintidós, dice la crónica./ Diecinueve varones, tres mujeres,/ dos niños de miradas aleladas,/ sesenta y tres disparos, cuatro credos,/ tres maldiciones hondas, apagadas,/ cuarenta y cuatro pies con sus zapatos,/ cuarenta y cuatro manos desarmadas,/ un solo miedo, un odio que crepita,/ y un millar de silencios extendiendo/ sus vendas sobre el alma mutilada. (Roca 91) 
El cierre es rotundo: como en el poema anterior, habla enumerativamente, en este caso de un suceso en particular, hasta llegar al silencio colectivo y a la convicción de que el alma está tan mutilada como los cuerpos desmembrados. Los objetos se equiparan en los sujetos funsionando miedo, odio, rabia, dolor y perplejidad. Los excesos de la violencia están sugestivamente representados en dos poemas.

"Caligrafía del dolor", llama Águeda Pizarro la poesía de Miryam Alicia Sendoya, al prologar su Muro de sombras y de pájaros (2015), Gran Premio Ediciones Embalaje del Museo Rayo en el 2014. La voz de los breves poemas se apoya en imágenes desgarradoras y condensadas que se desdoblan o yuxtaponen mientras velan y revelan la devastación. El yo poético carga su morral, es decir su existencia, como si fuera una tumba, y nombra campos huérfanos, un sol que llora, implacables pájaros hambrientos, migratorios, con las alas rotas o enlutados, niños que huyen, lugares deshabitados, en fin, signos del desamparo y el dolor. Así dice con ironía en este caleidoscopio atormentado: "a veces las alimañas aplauden a sus muertos", dice en el poema "XII" (Sendoya 12); y en "XI", aludiendo simultáneamente a los actos cometidos en épocas de la violencia bipartidista y a la no menos sanguinaria de los paramilitares, dice: "Lo desenterraron -como un árbol/ cercenaron sus brazos, su fuerza./ Arrancaron sus dientes, su risa./ despojaron sus raíces./ Vio pasar a sus muertos/ y en caravanas los fantasmas" (11). El paisaje también refleja la zozobra y el redoble de campanas se une a "los escapularios rotos" al nombrar la muerte en el poema "XVIII": "El sol lloró los valles/ sembrados de escapularios rotos,/ aturde la campana, acuchilla el silencio/ y enlutados pájaros cruzan el firmamento" (18); la imagen de los pájaros se desdobla en unos y otros poemas, y los destaca en su sobrevuelo sobre "campos desolados y huérfanos", en la "tierra mutilada", en los "pasos apresurados", en el "éxodo de niños", y en las "sonrisas colgadas al filo de la noche" que re refractan en el poema "XXII" (22). No cabe duda de que cada poema es un tránsito hacia el calvario de la muerte. 
Sobre este libro Águeda Pizarro habla en el prólogo de "una hermandad peregrina en el exilio. Una hermandad que incluye y protege tanto a las sombras vivas de los huidos como los fantasmas de los muertos en el conflicto." (Sendoya iv).

Una de las poetas más reconocidas por el profundo desgarramiento de su universo poético es Mery Yolanda Sánchez, quien como ella misma ha afirmado, ha hecho arte a partir de la infamia. Reflejando la podredumbre y el dolor, en "Salmo", de su antología Un día maíz (2010), dice: "Hace falta mucho detergente/ cuando mi país hasta en la ropa duele”, (M. Y. Sánchez 40). Incisiva, su palabra no hace concesiones. Sus poemas generalmente en prosa, a la vez que dicen tienen un tono sugestivo que obliga a detenerse en las imágenes y reflexionar en la crueldad de algunas de ellas, en el sentido del cuerpo atormentado, en los ojos quietos. En el prólogo a su antología Rostro de tierra (2011), Santiago Espinosa afirma: "Ningún poeta colombiano, de esta o de ninguna época, ha visto nuestras violencias con tanta cercanía” (M. Y. Sánchez 10). Evidentemente, su poética desgarrada muestra de manera reveladora las masacres, los desaparecidos y desplazados, el mundo escindido, las heridas, la orfandad individual y colectiva, en fin, la descomposición total que expresa apelando al cuerpo y al país que genera muertes.

Condensada y explícita, en pocas palabras totaliza el constante ritmo de la muerte, como se percibe en el conjunto de poemas de Un día Maíz, que citaremos en adelante. Un buen ejemplo es "Carta a Carlos Iván": "Pienso en ti/ para contestar/ el saludo de mis muertos. / Pienso en ti/ para olvidar la rumba/ donde los disparos/ son la partitura/ del himno nacional" (64). En su fluir poético destacan por igual el canto del río que corre con el aliento de la sangre imposible de lavar, del miedo, el luto, de la queja de los muertos, los ojos inmóviles de los amigos, y su palabra recrimina: "Los ejércitos aprenden los pasos de la marcha fúnebre, pero olvidan el canto que aplastan con sus botas", dice en "Pasajeros" (19). Y es cortante e implacable, como en "Los otros", al reflejar la truculencia ejercida por los paramilitares y sus motosierras: "No alcanzaron a sentir miedo. Cuando los cortaron el dolor llegó primero, la boca de la bota en la cara [...]. Los niños se 
volvieron ancianos amarrados a los alambres de púas [...]. Y sus sombras también son perseguidas, señaladas y marcadas desde los pájaros metálicos, dueños del cielo" (30).

Coherente con el tono grave del poema trágico, la vida en la muerte deja ver el viacrucis, la sangre derramada, el mundo siniestro, el país en guerra. No hay tiempo para el amor, como se percibe en "La guardilla": "Dos cuerpos se necesitan/ se dicen desde los poros. /Enredados en barrotes de humo/ escriben país en las paredes de la guerra" (43 a). Escribir "país en las paredes de la guerra", impone su tragedia y consigna la muerte violenta como parte de la identidad. De ahí la actitud vigilante, pues en cualquier momento irrumpe el horror que amenaza, y ante la herida y la desgarradura no sirven las palabras embellecidas o enmascaradas, ni la levedad de la metáfora.

Próxima a esta perspectiva, Luisa Fernanda Trujillo, tiene registros que oscilan entre lo erótico y lo thanático. Si nos detenemos en lo que implica el territorio de la muerte, los indicios ya están en su primer libro, De soslayo, prendada (2010), en el que miseria, orfandad, soledad y desamparo son denominador común, dice en "Culpa": "en una calle/ un niño hace viejos los zapatos de caminar descalzo// en una esquina/ un perro deja de jadear el hambre por un pedazo de pan/ para su dueño" (Trujillo 37). El cuadro es francamente desolador. Pero la fuerza de las imágenes varía cuando la crueldad se impone: el yo poético cierra los ojos y enmudece, los pájaros aprietan sus picos en señal de duelo y rasgan la tierra con las uñas, como en "Incertidumbre", de su antología Trazo en sesgo la noche (2012), donde afirma que "las huellas son iguales todas" y pregunta por "la senda de retorno// entre tantos pasos/ sin nombre//entre tanta fosa común// sobre el asfalto" (40).

El ritmo es tajante en su evolución poética: camina por la ciudad y entre el asfalto, mira las ventanas parecidas a cuencos vacíos y los ojos ven las cornisas donde se posan pájaros a punto de morir. Hay huellas callejeras anónimas, se oyen puertas cerrándose con estruendo, hiere el silencio de los muertos. Los sentidos se agudizan y la conciencia del país nombra el horror que asecha. Así da testimonio 
de aquello que ha visto suceder mientras camina a ciegas. El tono se sostiene en los poemarios bilingües publicados en Italia con traducción de Emilio Coco: En tierra el pájaro olvida cantar (2017) y Mi por siempre jamás (2019). En ellos cada día hay un duelo nuevo y lo expresa a través de una mirada que se ahonda porque "cuesta vivir en un país donde las voces/ se exorcizan en fiestas decembrinas" (Trujillo 28), como dice en uno de los poemas de En tierra el pájaro olvida cantar. En este poemario a veces hay un contrapunto entre la sensualidad y la violencia, aunque esta última sobresale, a veces interrumpe el amor y lo condena, como en "Si no hubiera guerra":

Si no hubiera guerra $[\ldots] /$ volvería a mirar a las lechuzas sin la compasión del insomnio de los búhos [...]/ Si la guerra no hubiera llegado a mí/ como llegó en la noche clandestina de una toma/ dormiría desnuda entre los pastizales/ dejaría a las lagartijas hacer cosquillas en mis muslos/ y sembraría de flores los nombres de los muertos. (Trujillo 34)

Pero la guerra se impone y pinta de rojo lo que toca y sella "las palabras en medio de las balas", dice más adelante. La voz poética pone los ojos en la muerte que se multiplica y lo reitera en distintos poemas, como en "Lo que cuesta vivir"):

Durante un año vi pasar doce ataúdes sin nombre/ sin carro fúnebre que acompañara su paso/ sin una primavera que ofrendara a la muerte el pistilo de una flor/ solo el golpe seco y tartamudo de las trancas/ atizaba las puertas de las casas,/ sacudía de los muros las balas dejadas por la última guerra. (28)

La muerte se desdobla en el asesinato a sueldo, y de lo general va a lo particular y a lo íntimo en una forma de conciencia individual que carga culpas y recriminaciones. Así se sostiene en "Esas llantas arrumadas en las calles": 
Esos ataúdes todos blancos hacen el desfile de la muerte por encargo/ Esas ventanas de un golpe cerradas/ tras otro golpe de la puerta/ Esos gritos y yo muda escondida tras la tapia/ Esa bala y otra bala y la ausencia de Fermín/ Esos ojos que me miran y señalan/ no me miren que me he ido que no veo/ que no existo/ Esa mancha pura sangre que no es mía y que es mía. (36)

El golpe de la puerta y de las balas, la mirada recriminatoria y el silencio asustado, el tartamudeo, la sangre propia y ajena, en fin; el sentirse acorralado, se sostienen hasta el verso final que asociado a un semáforo detenido en el color rojo "que no cambia", en su conjunto refleja el estado de quietud e inercia de una situación incontrolable en la que todos somos víctimas y victimarios: ríos de sangre. El poemario se expande en unos poemas y se repliega en otros, como en "Lo que cuesta vivir" donde las fiestas decembrinas se exorcizan y se velan una y mil veces, así como en "Si te dijera que por aquí también el sol se esconde", de Mi por siempre jamás, en el que con nostalgia recapitula historias:

Que en las noches de frío sopla desde el páramo/ y quema el borde de las uñas/ Que los árboles caídos aún respiran/ y que las balas recuerdan el impulso de la mano tensa/ de quien empuñó el arma/ [...] que un perro callejero revuelve la basura/ en la búsqueda de encontrar señales/ [...] Que el cementerio, en la montaña, / donde entierran los deshechos, / se ha venido abajo/ y que en el parque/ un reloj centenario detuvo sus agujas hace años/ para no tener que seguir contando muertos/ ¿Me creerías? (Trujillo 42)

El contraste se ve en el repliegue del poema "Esperé, esperé entera tu regreso", en el que la inútil espera semeja una estación vacía que solo deja oír el zumbido de las moscas, mientras “cada casa una veladora llora su pabilo" (107). 
Temas semejantes a los abordados también se encuentran en la poesía de Andrea Cote. La muerte y la ruina van y vienen sobre la escritura y la existencia, imponiéndose en los paisajes desolados y rotos que sugieren la casa destruida, arrasada, vacía, muerta. Como en Camila Charry, la casa es la patria, la tierra, el albergue, el cielo abolido del origen. Desde su primer poemario, Puerto calcinado (2003), el yo poético se desdobla y pide recordar, habla con la madre, el padre, se mira en María, y concentra la nostalgia que convoca ausencia, dolor, soledad y abandono de Dios. Esta casa pertenece a un puerto calcinado, quebrado, desecado, yermo, está anclada en la infancia, no tiene ni verbo, ni prodigio, ni padre (Cote 14), y allí solo se escucha "el silencio,/ que son treinta y dos ataúdes/ vacíos y blancos" (18). Entre lo individual y colectivo, nombra la tierra como una herida que sangra en todo y todos, o "abre agujeros/ para obligarnos a morir" (26). Como si con su visión desamparada fusionara las tristezas y angustias de las poetas anteriores, destaca ese lugar donde existe "un dolor/ en el centro del dolor" (33), mientras su yo poético husmea, escarba, inquiere, vela, revela y se rebela frente a ese mundo que obliga a abandonarlo todo.

No puede ser mayor la tragedia expresada en los textos de estos autores y autoras. Se trata de mirar la violencia a la cara, de exhumar las historias que muestran lo execrable y oscuro que la define. Las respectivas poéticas escuchan los

silencios y los ruidos, enfrentan horror y dolor, hacen memoria de las heridas y de la orfandad que deja.

\section{Bibliografía}

Alvarado Tenorio, Harold (Compilación) y Caballero, Antonio (Prólogo). Una generación desencantada. Bogotá: Universidad Nacional de Colombia, 1985.

Carranza María Mercedes. Poesía reunida y 19 poemas en su nombre. Bogotá: Letra a Letra. Reimpresión, 2016. 
Cote, Andrea. Puerto calcinado. Bogotá: Universidad Externado de Colombia, colección Un libro por centavos №2, 2003

Charry, Camila. Arde de Babel. Bogotá: Universidad Externado de Colombia, colección Un libro por centavos $\mathrm{N}^{\mathrm{o}}$ 135, 2017.

Ferrán, Jaime. Selección y prólogo. Antología de la generación sin nombre. Madrid, Adonais, 1970.

Giraldo, Luz Mary. "Poesía y poéticas de la Generación sin nombre”. Cuadernos de Literatura. Vol III, $\mathrm{N}^{\mathrm{o}}$ 6, Julio-Diciembre, pp 57-71. Bogotá, Departamento de Literatura, Pontificia Universidad Javeriana, 1997. . Selección y prólogo. Ellas cantan. Antología de poetas iberoamericanas. Bogotá: Universidad Externado de Colombia, colección Un libro por centavos, 2019.

Miranda, Álvaro. El bostezo de la mosca azul. Antología poética 1968-2019. Bogotá: Editorial Escarabajo. Buenos Aires: Abisinia Editorial, 2020.

Pardo, Jorge Eliécer. Los velos de la memoria. Paris: Éditions Vericuetos, 2014.

Parra Sandoval Rodrigo. Faraón Angola. Bogotá: Bruguera, 2011. . Museo de lo inútil. Bogotá: Ediciones B, 2012.

Restrepo, Laura. La multitud errante. Bogotá: Alfaguara, 2001

Roca, Juan Manuel. La casa sin sosiego. Bogotá: Taller de edición Rocca, 2007.

Sánchez Pinzón, Diana Carolina. Cae sobre mí una sombra. Bogotá: Universidad Externado de Colombia, colección Un libro por centavos No 149, 2018.

Sánchez, Mery Yolanda. Un día maíz. Bogotá: Universidad Externado de Colombia, colección Un libro por centavos $\mathrm{N}^{\mathrm{0}} 55,2010$. . Rostro de tierra. Cali: Universidad del Valle, 2011.

Trujillo, Luisa Fernanda. De soslayo, prendada. Bogotá: Fundación Palabra a Tiempo, 2010.

. Trazo en sesgo la noche. Bogotá: Universidad Externado de Colombia, colección Un libro por centavos $\mathrm{N}^{\circ}$ 81, 2012. - A terra, l'ucello dimentica di cantare. En tierra, el pájaro se olvida de cantar. Rimini: Rafaelli Editore, 2017.

. Mio per sempre mai. Mi por siempre jamás. Roma: Giulano Ladolfi Editore, 2019.

Vanegas Ahías, Beatriz (2015). Festejar la ausencia. Bogotá: Universidad Externado de Colombia, colección Un libro por centavos $\mathrm{N}^{\mathrm{o}} 113$.

$($ cc) $\mathbf{E Y}$

ULIS D-Sorle
New articles in this journal are licensed under a Creative Commons Attribution 4.0 United States License. 